\title{
First-time faculty librarian, first year experience \\ Overcoming tenure fears
}

W

hen I received the offer for my current position as technical services librarian, assistant faculty, I was both excited and terrified. Becoming a faculty librarian had been a career goal of mine because I had always wanted to be more involved in the academic community.

As I was weighing the pros and cons of accepting the position, I knew I could handle the technical services and reference job responsibilities because I had been performing similar duties for nearly seven years at my previous job. However, that position was not a faculty position.

As a result, I was not required to be on university committees or be more active in the library profession, even though I was a department head. Additionally, there was no encouragement to get involved, nor funds for me to do anything that was outside of the college as nonfaculty. I was grateful for electronic lists, for free online library-related webinars, and to my consortium for the free workshops that at least allowed me to keep abreast of some of the hot topics in the profession. I was also not required to publish, and that requirement of the new position was, and is, the most terrifying for me.

Publish. Never had a seven-letter word instilled such fear in me. As my prior position left me feeling out of touch with the profession, deciding to take the new position left me feeling overwhelmed. I did not come into this position with current research or previous publication experience, like some of my colleagues, because my two master's degrees did not require a thesis.

To get ideas on what I could write about, I was looking forward to getting back into the library world by attending a few conferences to find out what I had missed these past few years. Within my first month, a decision was made to support conference expenses for tenure track faculty who were accepted to present papers. No more going to conferences just to go. I had to have an accepted paper to present in order to attend.

Furthermore, I found out that I had skipped a year in the tenure process because I started the position in January 2015 instead of August 2014. This meant I would be turning in a Year Two portfolio in January 2016 instead of a Year One. Imagine my surprise when I found this out as I had not been working here a year. This meant that I had missed an entire

Cynthia A. Romanowski is technical services librarian at Governors State University in University Park, Illinois, email: cromanowski@govst.edu

(C) 2015 Cynthia A. Romanowski 
year in the tenure process. Not being able to show progress beginning with year one in the three areas of teaching/primary duties, research/creative activity, and service was a major concern. I was not worried as much about my primary duties because I have accomplished quite a bit these past few semesters, but showcasing progression in the other areas of the portfolio was an entirely different story.

I am a 12-month faculty member, so there are no semester breaks to do research. It had to be built into my work plan and workaround my primary duties. To add to my fear, it was originally thought that if I had not published something by the due date of my Year Three portfolio, which would be October 2016, then I would be let go. I was starting fresh, with a clean slate, and I was terrified because I felt as though my faculty hourglass had very little sand left.

The area of service was also a concern of mine. I applied and was rejected for a national committee, but I was accepted on a consortium committee. Because I began my position in January, there was no opportunity to obtain a seat on a university committee. I would have to wait until August for relief of this fear. When the university committees opened for new members, I was able to get a seat on the University Curriculum Committee.

Upon working on my Year Two portfolio, I was offered a glimmer of hope when I read my university library criteria for the tenure process. I had found out I would not have to produce a published item until my fifth year, as the focus had to be on primary duties for the first three years. To my relief, I had more time to get acclimated to my profession, once again.

As I have fought to overcome my fear, my colleagues and my dean have been my cheerleading group. They have been a vast source of advice and counsel during my challenging first year. They have offered to help me outline a research plan and have sent me links to websites or articles where I could get publishing ideas. They have even talked to me about collaborating on an article to help get my foot in the publishing door.

This experience has helped me realize that I need to have confidence in my abilities because that is how I got the job in the first place. It also has helped me to ask for help or advice because my colleagues really do want me to succeed, and I do not know everything. I have also learned to write about what I know and am interested in, even if it is not the hot topic in the field. It just may be useful to someone else. It also taught me to not get discouraged when faced with rejection letters. More importantly, I learned you should read and know your division criteria thoroughly for getting tenure to avoid future panic attacks.

Navigating one's first year faculty experience has many twists and turns. As a result, I decided to write this essay in hopes that it helps others be more at ease in a similar circumstance. $\boldsymbol{n}$

\section{Upcoming ACRL e-Learning}

ACRL is offering a variety of online courses and webcasts this winter. Upcoming topics include:

Planning, Running, and Learning from Focus Groups (Webcast: February 3, 2016)

The Library Workplace in the 21st Century (Online Course: February 22-March 12, 2016)

Discover ACRL's Frequent Learner Program to stretch your professional development funds.Visit the ACRL e-Learning website at www.ala.org/acrl/onlinelearning for complete details and a full listing of upcoming ACRL e-Learning events.

Additional learning opportunities are available through the ACRL-Choice webinar program. Learn more on the Choice website at www.choice360.org/acrl-choice-webinars. 